\title{
ICT as a Supporting Factor for Innovation Activities
}

\author{
Jovana Zoroja \\ University of Zagreb, Faculty of Economics and Business, Zagreb, Croatia
}

\begin{abstract}
Development and usage of information and communication technology (ICT) is continuously growing in the last 30 years. The main reason is that ICT has a great potential to improve the efficiency of business processes, to increase the competitiveness, but also to facilitate and drive innovations. Innovation has become a crucial factor for the economic development and ICT offer great opportunities in supporting innovation activities. The goal of the paper is to identify the influence of the usage of the ICT on the innovation activities in European countries. Data for the period of five years (2007-2011) were collected from the European statistical database - Eurostat and Global Competitiveness Report. In order to investigate the ICT impact on the Innovation and sophistication factor subindex of the European countries, we conducted a panel regression analysis. Research results showed that ICT support innovation activities. However, the ICT has the highest impact on the $11^{\text {th }}$ pillar: Business sophistication of the Global Competitiveness Index.
\end{abstract}

Keywords: Information and Communication Technology, Innovation, European Countries, Regression Analysis

JEL classification: C3, D8, D83, L86, O3

\section{Introduction}

Information and communication technology (ICT) has a key role in the economic development and prosperity especially in the last two decades (Morgan et al., 2006; Campisi et al., 2013). Using ICT could improve personal, economic and social development regarding communication, doing business and education (Vehovar, Lesjak, 2007; Higon, 2011). Individuals and companies are using ICT in their everyday activities, while the usage of ICT increases development of e-skills and the quality of education system, improve business processes and quality of products/services, encourages employment and strengthen relationship with customers and partners. ICT diffuse through every aspect of an organizations' value chain and enable sharing information, resources and knowledge between employees (Haseeb, 2015).

The ICT sector is a crucial factor for the socio-economic growth in many countries, especially in achieving competitive advantage through reducing costs, increasing diversification and facilitating cooperation with partners, suppliers and customers. Development and usage of ICT lead to higher global competitiveness through three steps: (i) transform industry structure and competition rules, (ii) establish sustainable competitive advantage and new competitive possibilities (iii) generate new and unique business processes (Haseeb, 2015). The best examples of the most developed and competitive countries in the world are Finland, Sweden and Singapoure, which are one of the top three the best-performing countries according to Network Readiness Index for the last five years (2011-2015) (WEF-The Global Information Technology Report, 2011-2015; Yunis et al., 2012). In addition, three mentioned countries are also leaders in the field of innovation activities (WEF-The Global 
Competitiveness Index, 2011-2015). Finlad is in the top five, while Sweden is in the top ten regarding Global Competitiveness subindex: Innovation and sophistication factor in the last five years and their position is going better through years. Singapoure is in the top 13 but due to an outstanding performance across all the dimensions of Global Competitiveness Index (GCl) it is expected to improve its position in the future regarding innovation activities.

Development of ICT provides higher efficiency gains, as well as higher level of innovation activity. Innovation could be defined as an adoption of a new idea that enables organizations to achieve sustain competitive advantage (Grolleau et al., 2013). In other words, innovations present a new way of organizing business which can be significantly improved by ICT usage (Haseeb, 2015). Therefore, the most developed and innovative organizations are those which are developing and using ICT to facilitate and drive innovations in business processes and in the products and services (Arvanities, 2013). Up-to-date progress in ICT offers great opportunities for organizations' research and development (R\&D) activities which lead to higher innovation performance (Kleis et al., 2012). Continuously innovations enable better market position and competitive advantage.

The goal of this paper is to analyse the influence of ICT usage on innovation, measured by the one of the three main subindexes of the competitiveness index: Innovation and sophistication factor subindex. Therefore, we selected the four main fields of ICT applications: eLearning, personal Internet usage, eBusiness, eScience and technology transfer and eGovernment (Blackman, 2004; Zott et al., 2000). Data have been collected from the European statistical database - Eurostat (Eurostat, 2015) and from the World Economic Forum (WEF-The Global Competitiveness Report, 2007-2011). The panel regression method has been conducted on a sample of selected European countries.

The paper is structured in five sections. Introduction is the first section of the paper. In the second section methodology and data are described. The results are presented in the third section. The major implications are discussed in the fourth section. Finally, the last section concludes the paper.

\section{Methodology and data}

The goal of this paper is to determine the role of ICT as a supporting factor for innovation activities for European countries. In order to analyse the influence of ICT usage on innovation we have conducted panel regression analysis. Panel regression analysis presents a statistical method using two and " $n$ " dimensional panel data. The data are usually collected over time and for the same group of units and a regression is run over these two dimensions. Panel regression provides evaluation of the influence of independent variables to the dependent variables over the time. Therefore, we can analyse the change of innovation performance as the result of ICT usage over five year period (2007-2011).

Data on ICT usage and on innovation performance for 32 European countries have been collected in the period from 2007 to 2011 . Beside 28 European countries the data have also been collected for Iceland, Norway, Macedonia and Turkey. Other European countries were not used in the analysis because of missing data for selected variables and for selected years. Data were collected from the European statistical database - Eurostat (Eurostat, 2015) and from the Global Competitiveness Report issued annually by the World Economic Forum (WEF-The Global Competitiveness Report, 2007-2011).

ICT can be used in many different areas, e.g. education, business, health, private issues, science and technology, public services (Blackman, 2004, Zott, 2000). 
Therefore, we selected the five main areas of ICT usage for our analysis: elearning, Internet usage, eBusiness, escience and technology transfer and eGovernment. Data on ICT usage have been collected for 17 variables from the European statistical database - Eurostat (Eurostat, 2015) and are used as independent variables. Eight variables out of 17 refer to the ICT usage of individuals aged 16 to 74 and are shown in percentage (eLearning, Internet usage and eGovernment). Other nine variables refer to the ICT usage of companies (eBusiness, escience and technology transfer) with at least ten employees and are shown in percentage.

The area of e-Learning was analysed using four variables: (i) eLRN1: Purchase of materials for e-learning, (ii) eLRN2: Search of information on education and training, (iii) eLRN3: Use of the Internet for education and training and (iv) eLRN4: Use of the Internet for decision-making on learning. Variables which refer to personal Internet usage are: (i) IntUSG 1: Use of online banking and (ii) IntUSG2: Use of the Internet for finding an employment. Variables related to the area of e-Government are: (i) eGOV1: Using public administration sites to send forms and (ii) eGOV2: Communication with public departments.

The selected variables which refer to the area of eBusiness are: (i) eBUS1: CRM software usage, (ii) eBUS2: Internet purchase and (iii) eBUS3: Ordering via Internet. The selected variables related to the area of escience and technology transfer are: (i) eSCNtechTR1: High-technology import within EU27, (ii) eSCNtechTR2: High-technology import outside EU27, (iii) eSCNtechTR3: High-technology import in the world, (iv) eSCNtechTR4: High-technology export within EU27, (v) eSCNtechTR5: High-technology export outside EU27 and (vi) eSCNtechTR6: High-technology export in the world.

Data on innovation performance are collected from the World Economic Forum (WEF-The Global Competitiveness Report, 2007-2011) which measures competitiveness of 142 countries all over the world. Qualitative and quantitative data are collected from statistical offices from particular country and are used for computing the $\mathrm{GCl}$. $\mathrm{GCl}$ is composed of three subindices (Efficiency enhancers subindex, Basic requirements subindex and Innovation and sophistication factor subindex) and 12 pillars of competitiveness (Institutions, Infrastructure, Macroeconomic environment, Health and primary education, Higher education and training, Goods market efficiency, Labour market efficiency, Financial market development, Technological readiness, Market size, Business sophistication and Innovation).

In our research, country's innovation performance is used as the dependent variable. We used data for the Innovation and sophistication factor subindex and its two pillars: Business sophistication and Innovation for 32 selected European countries in the five year period (2007-2011). In order to calculate country's rank and $\mathrm{GCl}$ scores for innovation performance different data regarding business sophistication and R\&D innovation are collected (Table 1). Innovation and sophistication factor subindex refers mostly to countries which are leaders on the global market where companies are trying to improve their business by innovative strategies and products. Producing new and unique products by using sophisticated business processes and through innovation, companies are trying to achieve sustainable competitive advantage and higher standard of living. Business sophistication refers to quality of a country's business networks and of firms' business processes which lead to higher innovative performance and efficiency and to increased productivity. The final pillar of $\mathrm{GCl}$ refers to innovation, especially technological innovation, which are important for socio-economic progress of countries. Higher standards of living can be increased only by innovative activity in public and private sectors. Countries which are encouraging innovative activities also invest in research and 
development, enhance quality of scientific and research institutions and foster collaboration between universities and industry (WEF-The Global Competitiveness Report, 2011).

Table 1

Global Competitiveness Index: Innovation and Sophistication Factors Subindex

\begin{tabular}{ll}
\hline INNOVATION AND SOPHISTICATION FACTORS \\
\hline $11^{\text {th }}$ pillar: Business sophistication \\
$11.01 \quad$ Local supplier quantity \\
11.02 & Local supplier quality \\
11.03 & State of cluster development \\
11.04 & Nature of competitive advantage \\
11.05 & Value chain breadth \\
11.06 & Control of international distribution \\
11.07 & Production process sophistication \\
11.08 & Extent of marketing \\
11.09 & Willingness to delegate authority \\
$11^{\text {th }}$ pillar: Innovation \\
12.01 Capacity for innovation \\
12.02 Quality of scientific research institutions \\
12.03 Company spending on R\&D \\
12.04 University-industry collaboration in R\&D \\
12.05 Gov't procurement of advanced tech products \\
12.06 Availability of scientists and engineers \\
12.07 Utility patents per million population \\
\hline
\end{tabular}

Source: The Global Competitiveness Report 2010-2011, World Economic Forum

\section{Results}

The goal of the paper was to evaluate influence of the ICT as a supporting factor on countries' innovation activities. In order to estimate the relation between ICT and innovation performance of the countries we have conducted the panel regression analysis.

In Table 2 are shown regression coefficients and goodness of fit for all regression models. Three dependent variables are shown in header row: Innovation and Sophistication Factors, Business sophistication and Innovation. Indicators of ICT usage by individuals and enterprises are divided into five areas (elearning, personal Internet usage, eBusiness, escience and technology transfer and eGovernment) and present independent variables which are shown in the first left column.

The highest number of independent variables impacts the $\mathrm{GCl} 11^{\text {th }}$ pillar (Business sophistication) (53\%). All variables regarding eLearning and personal Internet usage influence on the Business sophistication while from other three ICT areas at least one variable influence on $11^{\text {th }}$ pillar. There is the same number of independent variables which influence the Innovation and Sophistication Factors Subindex and $12^{\text {th }}$ pillar Innovation (35\%).

Coefficients of determination range from 0.758 to 0.790 . Value of coefficients of determination adjusted (adjusted-R2) is a bit lower and range from 0.729 to 0.765 . It can be concluded that both measures indicate adequate goodness of fit for all of the models.

Table 2 
Panel regression analysis results - summary of estimates of regression coefficients and coefficients of determination

\begin{tabular}{|c|c|c|c|}
\hline \multirow{2}{*}{ ICT variables } & \multirow{2}{*}{$\begin{array}{c}\text { GCl subindex } \\
\text { Innovation and } \\
\text { Sophistication Factors }\end{array}$} & \multicolumn{2}{|c|}{$\mathrm{GCl} 11^{\text {th }}$ and $12^{\text {th }}$ pillars } \\
\hline & & $\begin{array}{c}\text { Business } \\
\text { sophistication }\end{array}$ & Innovation \\
\hline Intercept & $3,046^{* * *}$ & $3,626^{* * *}$ & $2,563^{* * *}$ \\
\hline eLRN1 & $0,026^{* * *}$ & $0,024^{* * *}$ & $0,030^{* * *}$ \\
\hline eLRN2 & $-0,008$ & $-0,012^{* * *}$ & $-0,004$ \\
\hline eLRN3 & 0,019 & $0,022^{* *}$ & 0,012 \\
\hline eLRN4 & $-0,014$ & $-0,017^{* *}$ & $-0,009$ \\
\hline IntUSG 1 & $0,009^{* * *}$ & $0,008^{* *}$ & $0,011^{* * *}$ \\
\hline IntUSG2 & $-0,016^{* *}$ & $-0,020^{* * *}$ & $-0,009$ \\
\hline eBUS1 & 0,008 & 0,008 & 0,006 \\
\hline eBUS2 & $0,016^{* * *}$ & $0,017^{* * *}$ & $0,013^{* * *}$ \\
\hline eBUS3 & $-0,011^{* *}$ & $-0,008$ & $-0,008$ \\
\hline eSCNtechTR1 & $-0,001$ & $-0,009$ & $-0,002$ \\
\hline eSCNtechTR2 & $-0,027^{* * *}$ & $-0,024^{* * *}$ & $-0,027^{* * *}$ \\
\hline eSCNtechTR3 & 0,040 & 0,043 & 0,041 \\
\hline eSCNtechTR4 & 0,035 & 0,001 & $0,054^{* *}$ \\
\hline eSCNtechTR5 & 0,017 & 0,001 & $0,025^{* *}$ \\
\hline eSCNtechTR6 & $-0,032$ & 0,009 & $-0,055$ \\
\hline eGOV1 & $-0,005$ & $-0,008$ & $-0,002$ \\
\hline eGOV 2 & 0,007 & $0,009 * *$ & 0,004 \\
\hline \multicolumn{4}{|c|}{ Model validation } \\
\hline R2 & 0,790 & 0,758 & 0,770 \\
\hline Adjuster R2 & 0,765 & 0,729 & 0,742 \\
\hline \multicolumn{4}{|c|}{$\%$ of statistically signific ant variables } \\
\hline 17 variables $(100 \%)$ & $35 \%$ & $53 \%$ & $35 \%$ \\
\hline
\end{tabular}

Source: Authors' survey (Eurostat, WEF)

Note: ${ }^{* * *}$ statistically significant at $1 \%,{ }^{* *}$ statistically significant at $5 \%$

\section{Discussion}

Table 3 presents the relation among individual independent variables which refer to the five areas of ICT usage (eLearning, personal Internet usage, eBusiness, escience and technology transfer and eGovernment) and dependent variables (Innovation and sophistication factor subindex, Business sophistication and Innovation). In order to present the level of statistical significance we have used thresholds of $1 \%$ and $5 \%$ with the sing in the parenthesis which represents the positive or negative sign of the regression coefficient.

There is a positive relation between all innovation indices (Innovation and Sophistication Factors subindex, Business sophistication and Innovation) and elearning indicator which refers to buying materials via Internet (eLRN1: Purchase of materials for e-learning). There is also positive relation among $\mathrm{GCl} 11^{\text {th }}$ pillar Business sophistication and elearning indicator which refers to use of Internet for education (eLRN3: Use of the Internet for education and training). There is negative relation between $\mathrm{GCl} 11^{\text {th }}$ pillar Business sophistication and two elearning indicators which measure passive usage of elearning tools (eLRN2: Search of information on education and training and eLRN4: Use of the Internet for decision-making on learning). Passive usage of eLearning regarding search of information and decision making could explain negative relationship between $\mathrm{GCl} 11^{\text {th }}$ pillar Business 
sophistication and two elearning indicators. Development and usage of elearning in developing countries is still lagging behind compared to elearning market in developed countries. Therefore, there is a great potential of elearning usage in developing countries. elearning encourages innovation approach in education system because it provides exchange of knowledge and information, offers lifelong learning, facilitates learning among students from different countries (Florea, 2010; Bocconi et al., 2013).

Table 3

Level of statistical significance of independent variables

\begin{tabular}{|c|c|c|c|}
\hline \multirow{2}{*}{ ICT variables } & \multirow{2}{*}{$\begin{array}{c}\text { GCI subindex } \\
\text { Innovation and } \\
\text { Sophistication Factors }\end{array}$} & \multicolumn{2}{|c|}{ GCl $11^{\text {th }}$ and $12^{\text {th }}$ pillars } \\
\hline & & $\begin{array}{c}\text { Business } \\
\text { sophistication }\end{array}$ & Innovation \\
\hline eLRN1 & $1 \%(+)$ & $1 \%(+)$ & $1 \%(+)$ \\
\hline eLRN2 & & $1 \%(-)$ & \\
\hline eLRN3 & & $5 \%(+)$ & \\
\hline eLRN4 & & $5 \%(-)$ & \\
\hline IntUSG1 & $1 \%(+)$ & $5 \%(+)$ & $1 \%(+)$ \\
\hline IntUSG2 & $5 \%(-)$ & $1 \%(-)$ & \\
\hline \multicolumn{4}{|l|}{ eBUS1 } \\
\hline eBUS2 & $1 \%(+)$ & $1 \%(+)$ & $1 \%(+)$ \\
\hline eBUS3 & $5 \%(-)$ & & \\
\hline \multicolumn{4}{|l|}{ eSCNtechTR1 } \\
\hline eSCNtechTR2 & $1 \%(-)$ & $1 \%(-)$ & $1 \%(-)$ \\
\hline \multicolumn{4}{|l|}{ eSCNtechTR3 } \\
\hline eSCNtechTR4 & & & $5 \%(+)$ \\
\hline eSCNtechTR5 & & & $5 \%(+)$ \\
\hline \multicolumn{4}{|l|}{ eSCNtechTR6 } \\
\hline \multicolumn{4}{|l|}{ eGOV1 } \\
\hline eGOV 2 & & $5 \%(+)$ & \\
\hline
\end{tabular}

Source: Authors' survey (Eurostat, WEF)

There is a positive relation between all innovation indices (Innovation and Sophistication Factors subindex, Business sophistication and Innovation) and Internet usage which refers to online banking (IntUSG 1: Use of online banking). There is negative relation between $\mathrm{GCl}$ subindex Innovation and Sophistication Factors and $\mathrm{GCl} 11^{\text {th }}$ pillar Business sophistication and Internet usage regarding finding employment via Internet (IntUSG2: Use of the Internet for finding an employment). Less developed countries do not encourage enough innovation activities in their socio-economic development. Therefore, looking for a job via Internet is not a common way in developing countries. Developed countries are trying to increase their competitiveness through new processes, products, applications, which is the reason for the ICT usage in bank sector for offering new and unique services via Internet for their clients (Cho, Park, 2012). Usage of ICT applications in financial business enhance innovation and increase quality of financial services for the clients.

There is a positive relation between all innovation indices (Innovation and Sophistication Factors subindex, Business sophistication and Innovation) and eBusiness indicator which measures active use of Internet by enterprises (eBUSS2: Selling goods or services over Internet). Using new and unique software applications contribute to innovative way of doing business, which increase competitive advantage of companies (Poon, 2008). There is negative relation between 
Innovation and sophistication factor subindex and eBusiness indicator related to placing orders over the Internet (eBUSS3: Ordering via Internet). One of the reasons could be confidence when ordering via Internet. This negative impact could also be stimulation for ICT experts to invent innovative and secure application for ordering via Internet.

There is a positive relation between $\mathrm{GCl}$ 12th pillar Innovation and two eScience and technology transfer indicators (eSCNtechTR4: High-technology export within EU27 and eSCNtechTR5: High-technology export outside EU27). There is negative relation between all innovation indices (Innovation and Sophistication Factors subindex, Business sophistication and Innovation) and escience and technology transfer indicator (eSCNtechTR2: High-technology import outside EU27). eScience and technology transfer refer to exchange of knowledge, ideas and information among scientific and research institutions and enterprises which has positive impact to business innovation (Rogers et al., 2001).

There is positive relationship between the $\mathrm{GCl} 11^{\text {th }}$ pillar Business sophistication with the indicator measuring active use of eGovernment by individuals (eGOV2: Communication with public administration units). eGovernment services are important for implementing innovative changes and new services in public institutions which lead to higher quality of business processes and satisfied clients (Irani et al., 2008).

\section{Conclusion}

In this paper the main goal was to estimate the impact of ICT on innovation activities in European countries. After the panel regression analysis was conducted, research results confirmed the influence of ICT as a supporting factor for innovation activities. It is important to highlight that there is a positive relation between all innovation indices (Innovation and Sophistication Factors subindex, Business sophistication and Innovation) and three independent variables (eLRN1: Purchase of materials for elearning; IntUSG 1: Use of online banking and eBUS2: Internet purchase) regarding three different ICT areas (elearning, eBusiness and eGovernment). It can be concluded that development and usage of ICT have strong influence on innovation and business sophistication, while it lead to higher innovation performance.

The limitation of this study is that time delay was not included in panel regression analysis. We have used $\mathrm{GCl}$ indices regarding innovation activities and for selected European countries. These mentioned limitations could be overwhelmed by future research. In order to expand this research, the panel regression analysis with time delay should be conducted on newer time period and for more number of countries. It is also important to include some other innovation indicators in further analysis and to investigate how particular country encourages innovation strategies.

\section{References}

1. Arvanitis, S. (2013), "The Effect of Soft ICT Capital on Innovation Performance of Greek Firms", Journal of Enterprise Information Management, Vol. 26 No. 6, pp. 679-701.

2. Blackman, C. (2004), "Stumbling along or Grave New World? Towards Europe's Information Society", Foresight, Vol. 6 No. 5, pp. 261-270.

3. Bocconi, S., Kampylis, P., Punie, Y. (2013), "Framing ICT-Enabled Innovation for Learning: the Case of One-to-One Learning Initiatives in Europe", European Journal of Education, Research, Development and Policy, Vol. 48 No.1, pp. 113-130.

4. Campisi D., De Nicola, A., Farhadi, M., Mancuso, P. (2013), "Discovering the Impact of ICT, FDI and Human Capital on GDP: A Cross-Sectional Analysis", International Journal of Engineering Business Management, Vol. 5, pp. 1-10. 
5. Cho, D.H., Park, J.H. (2012), "Examining the Performance of Internet-Based Business Models: Evidence from the Internet Banks", International Journal of $u$ - and e- Service, Science and Technology, Vol. 5 No. 1, pp. 51-61.

6. European Commission Database - Eurostat (2015), available at: http://ec.europa.eu/eurostat (accessed April 14th 2015)

7. Florea, N.V. (2010), "New Forms of Human Resources Development: E-learning in Education", Buletinul - Universitatii petrol-Gaze din Ploiesti, Vol. 62 No. 1A, pp. 249-257.

8. Grolleau, G., Mzoughi, N., Pekovic, S. (2013), "Is there a relationship between workplace atmosphere and innovation activities? An Empirical Analysis among French Firms", Economics of Innovation and New Technology, Vol. 22 No. 6, pp. 566-580.

9. Haseeb, H.M. (2015), "The Role of ICT Management to Achieve Organizational Innovation", The International Journal of Organizational Innovation, Vol. 7 No. 4, pp. 48-57.

10. Higon, D.A. (2011), "The Impact of ICT on Innovation Activities: Evidence for UK SMEs, International Small Business Journal, Vol. 30 No. 6, pp. 684-699.

11. Irani, Z., Love, P.E.D., Jones, S. (2008), "Learning Lessons from Evaluating eGovernment: Reflective Case Experiences that Support Transformational Government", The Journal of Strategic Information Systems, Vol. 17 No. 2, pp. 155-164.

12. Kleis, L., Chwelos, P., Ramirez, R., Cockburn, I. (2012), "Information Technolgy and Intangible Output: The Impact of IT Investment on Innovation Productivity", Information Systems Research, Vol. 23 No. 1, pp. $42-59$.

13. Morgan A., Colebourne, D., Thomas, B. (2006), "The Development of ICT Advisors for SME Businesses: An Innovative Approach", Technovation, Vol. 26 No. 8, pp. 980-987.

14. Poon, S. (2008), "Future of Small Business E-Commerce", Becker, A. (ed.), in Electronic Commerce Concepts, Methodologies, Tools and Applications, IV, pp. 1466-1473.

15. Rogers, E.M., Takegami, S., Yin, J. (2001), "Lessons Learned about Technology Transfer", Technovation, Vol. 21No. 4, pp., 253-261.

16. Tarute, A., Gatautis, R. (2014), "ICT Impact on SMEs Performance", Contemporary Issues in Business, Management and Education 2013, Procedia - Social and Behavioral Sciences, Vol. 110, pp. 1218-1225.

17. Vehovar, V., Lesjak, D. (2007), "Characteristics and Impacts of ICT Investments: Perceptions among Managers", Industrial Management and Data Systems, Vol. 107 No. 4, pp. 537-550.

18. World Economic Forum - The Global Competitiveness Report (2007-2015), available at: http://www.weforum.org/ (accessed April 21 th 2015)

19. World Economic Forum - The Global Information Technology Report (2011-2015), available at: http://www.weforum.org/ (accessed May $21^{\text {th }}$ 2015)

20. Yunis M.M., Koong K.S., Liu L.C., Kwan R., Tsang P. (2012), "ICT Maturity as a Driver to Global Competitiveness: A National Level Analysis", International Journal of Accounting and Information Management, Vol. 20, pp. 255-281.

21. Zott, C., Amit, R., Donlevy, J. (2000), "Strategies for Value Creation in E-Commerce: Best Practice in Europe", European Management Journal, Vol. 18 No. 5, pp. 463-475.

\section{About the author}

Jovana Zoroja, PhD, is a teaching and research assistant at the Faculty of Economics and Business, University of Zagreb, Department of Informatics, where she received her PhD with the dissertation thesis "Influence of the Information and Communication Technologies on the Competitiveness of the European Union Countries". She was educated at the LSE-Summer School in London in the field of Business Development and ICT Innovation. Her main research interests are information and communication technology, e-learning, simulation games and simulation modelling. She is actively engaged in number of scientific projects (FP7-ICT, Erasmus-Preparatory visit, bilateral cooperation, national projects). Jovana Zoroja published several scientific papers in international and national journals and participated in many scientific international conferences. Author can be contacted at jzoroja@efzg.hr 